\title{
Rancang Bangun Timbangan Digital Berbasis Sensor Beban 5 Kg Menggunakan Mikrokontroler Atmega328
}

Edwar Frendi Yandraa, Boni pahlanop Lapanporo ${ }^{a *}$, Muh. Ishak Jumaranga

\author{
aProdi Fisika, FMIPA Universitas Tanjungpura, Jalan Prof. Dr. Hadari Nawawi, Pontianak, Indonesia \\ *Email : boni8poro@gmail.com
}

\begin{abstract}
Abstrak
Telah dibangun sebuah prototipe alat untuk mengukur massa, gaya berat dan massa jenis menggunakan mikrokontroler ATMega328. Sistem pengukuran massa dan gaya berat berdasarkan prinsip kerja sensor beban $5 \mathrm{Kg}$. sedangkan untuk pengukuran massa jenis menggunakan prinsip kerja sensor beban dan sensor ultrasonik PING HC SRO4. Pada pengukuran massa jenis benda digunakan prinsip perubahan volume air dalam tabung. Selanjutnya digunakan mikrokontroler ATMega328 sebagai pengolah data secara keseluruhan. Tahapan penelitian meliputi proses perancangan, pembuatan dan pengujian alat. Hasil eksperimen menunjukan bahwa kinerja alat ini mampu mengukur massa 5 gram sampai dengan 4000 gram dengan error pengukuran sebesar 1,05\%. Sedangkan error pengukuran massa jenis yang dibaca alat ini sebesar 1,64\%. Hasil pembacaan dari alat memerlukan waktu sekitar lima detik untuk dijadikan acuan identifikasi data yang dihasilkan.
\end{abstract}

Kata kunci : sensor beban, mikrokontroler, sensor ultrasonik

\section{Latar Belakang}

Timbangan adalah sebuah alat bantu yang digunakan untuk mengetahui berat suatu benda. Jenis timbangan yang digunakan bermacammacam, mulai dari timbangan manual, timbangan mekanik hingga timbangan digital. Timbangan digital merupakan alat ukur untuk mengukur masa benda atau zat dengan tampilan digital. Dalam pemanfaatannya timbangan digunakan di berbagai bidang, dari bidang perdagangan, industri sampai dengan perusahaan jasa [1]. Timbangan digital mempunyai tingkat ketelitian yang lebih baik dan pengoperasian yang lebih efisien dari pada timbangan analog. Pengguna hanya melihat angka yang tertera pada layar LCD (Liquid Crystal Display) [2].

Saat ini pemanfaatan kedua jenis timbangan ini hanya digunakan untuk mengukur besaran massa saja. Timbangan digital dengan keluaran massa saja tidak cukup untuk digunakan dalam menentukan gaya berat yang bekerja pada sebuah benda dengan massa tertentu. Timbangan analog juga sangat sulit jika dibuat untuk keluaran yang banyak selain satu jenis keluaran. Hampir semua timbangan sudah menggunakan teknologi pengukuran secara digital dengan hasil pengukuran yang lebih akurat [3]. Dalam pembuatan timbangan digital, perusahaan menggunakan sensor dan transduser untuk mengukur berat beban yang berbentuk mekanik. Yaitu sensor beban (load cell) yang terdapat strain gauge di dalam sensor beban tersebut [4].
Dalam penelitian ini, dirancang dan dibuat sebuah alat timbang elektronik menggunakan mikrokontroler sebagai pengendali. Timbangan digital dengan keluaran massa saja tidak cukup untuk digunakan dalam menentukan gaya berat yang bekerja pada sebuah benda dengan massa tertentu. Pada timbangan elektronik ini, digunakan sensor beban dengan beban maksimal $5 \mathrm{Kg}$ sebagai pendeteksi massa maupun berat benda yang ditimbang [5]. Alat ini juga mampu mengukur massa jenis benda dengan menggunakan sensor ultrasonik untuk menghitung kenaikan volume benda. Sebelum benda diletakkan di atas timbangan, pengguna dapat memilih parameter apa yang akan menjadi output alat ini. Pilihan yang ada pada alat ini yaitu massa, gaya berat dan massa jenis.

\section{Metodologi}

\subsection{Alat dan Bahan}

Alat-alat yang digunakan adalah bread board, multimeter, power suplay. Bahan-bahan yang digunakan adalah mikrokontroler ATMega328, LCD 16x4, sensor beban $5 \mathrm{Kg}$ (load cell weighing sensor), Module HX711 sebagai penguat, Sensor ultrasonik PING HC SR04, kaca akrilik, lampu LED.

\subsection{Perancangan Hardware}

Sistem pengukuran timbangan digital yaitu dengan mendeteksi berat obyek, kemudian IC HX711 mengkonversi perubahan yang terukur dalam perubahan resistansi dan mengkonversinya ke dalam besaran tegangan (sebagai penguat hasil pembacaan sensor 
beban). Selanjutnya hasil pembacaan yang masih berupa data analog itu kemudian diolah di tempat proses data dan pengkondisian sinyal melalui pin analog mikrokontroler ATMega328 yang akan mengubah data analog tersebut menjadi keluaran digital (dengan masuk pada pin ADC pada mikrokontroler ATMega328). Setelah keluaran digital didapatkan maka hasilnya akan ditampilkan di layar LCD 16x4.

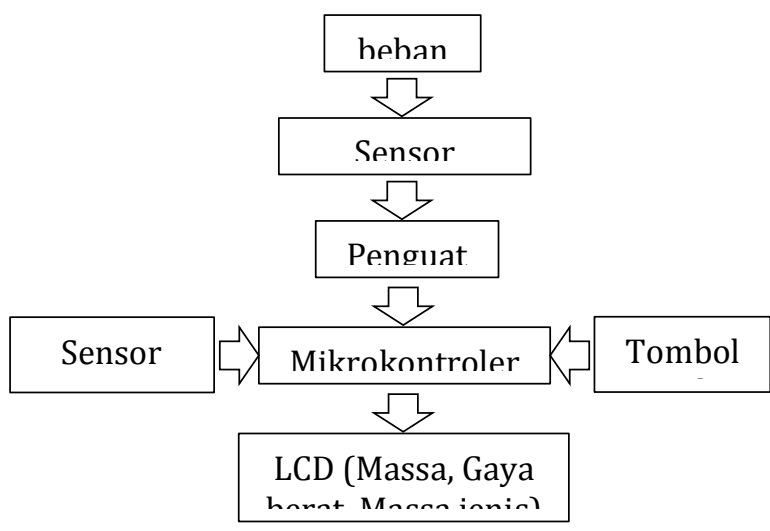

Gambar 1. Diagram blok perancangan sistem

\subsection{Perancangan sistem elektronik}

Diagram blok rangkaian sistem pengukuran timbangan benda terbagi menjadi 8 bagian, yaitu:

1. Sensor beban $5 \mathrm{Kg}$; adalah sensor yang digunakan untuk mengukur massa benda.

2. Module HX711; adalah penguat output dari sensor masa.

3. Sensor Ultrasonik HC SR04; adalah sensor jarak yang digunakan sebagai pendeteksi perubahan volume benda.

4. Tombol Reset; bagian input sistem yang berperan sebagai sinyal ke bagian mikrokontroler untuk menyatakan bahwa hasil pengukuran timbangan kembali ke nol.

5. Mikrokontroler; bagian perangkat utama atau dapat dikatakan sebagai otak dari sistem yang akan dibuat. Mikrokontroler yang digunakan adalah seri ATMega328.

6. LCD $16 \times 4$; merupakan bagian perangkat yang menampilkan hasil pengukuran massa benda dalam bentuk digital.

7. LED Indikator; Merupakan bagian yang memberikan pertanda bahwa sistem dalam keadaan nyala atau beroperasi.

8. Sumber tegangan.

Perancangan sistem elektronik secara keseluruhan dapat dilihat pada Gambar 2 sebagai berikut:

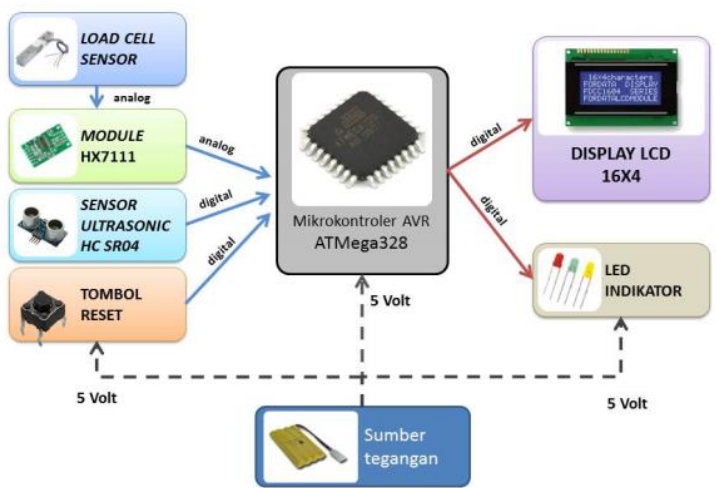

Gambar 2. Perancangan Sistem Elektronik

Sensor jarak yang digunakan pada penelitian ini adalah sensor ultrasonik HC SR04. Sensor ini bekerja pada tegangan $5 \mathrm{~V}$ dengan kuat arus listrik $15 \mathrm{~mA}$. Rentang jarak yang diukur yaitu dari $2 \mathrm{~cm}$ sampai $300 \mathrm{~cm}$.

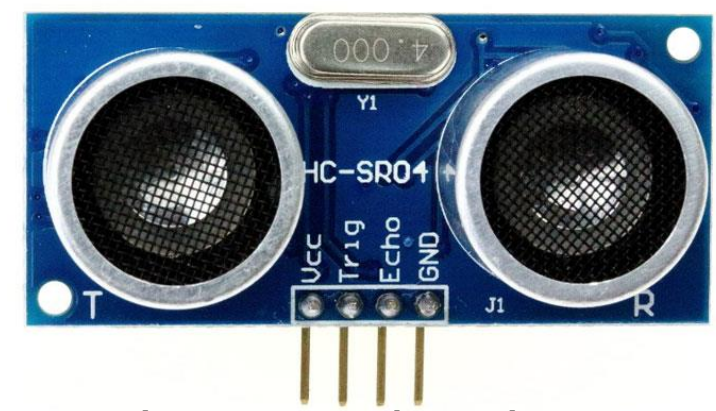

Gambar 3. Sensor Ultrasonik HCSR04

Pada Gambar 3 terdapat pin echo dan pin trigger. Pin echo dihubungkan dengan pin 8 pada perangkat arduino. Sedangkan pin trigger dihubungkan ke pin 7. Berikut merupakan cara kerja sensor ultrasonik ini [6]:

1. Sensor mendeteksi jarak objek dengan cara memancarkan gelombang ultrasonik (40 $\mathrm{kHz})$ selama $t_{\text {burst }}(200 \mu \mathrm{s})$ kemudian mendeteksi pantulan.

2. Sensor akan memancarkan gelombang ultrasonik sesuai dengan kontrol dari mikrokontroler pengendali (pulsa trigger dengan $t_{\text {out }}$ (minimal 2us). Gelombang ultrasonik merambat melalui udara dengan kecepatan $344 \mathrm{~m} / \mathrm{s}$ mengenai objek dan memantul kembali ke sensor.

3. Lebar pulsa $t_{\text {in }}$ akan menyesuaikan lama waktu tempuh gelombang elektronik untuk dua kali ukur jarak dengan objek.

\subsection{Perancangan sistem keseluruhan}

Perancangan sistem secara keseluruhan ini merupakan penggabungan dari perancangan bagian hardware, elektronik serta pemrograman. Alat ini menggunakan sensor beban untuk mendeteksi massa benda yang 
akan ditimbang. Prinsip kerja dari alat ini yaitu jika terjadi pertambahan berat, maka sensor akan mulai mendeteksi berat benda. Kemudian keluaran sensor yang berupa perubahan resistansi ini akan diubah menjadi perubahan tegangan oleh rangkaian mikrokontroler. Rangkaian Analog Digital Converter (ADC) yang terdapat pada mikrokontroler ini akan mengubah sinyal analog menjadi sinyal digital. Hasil konversi ${ }^{5 \text { voudari }}$ rangkaian ADC akan

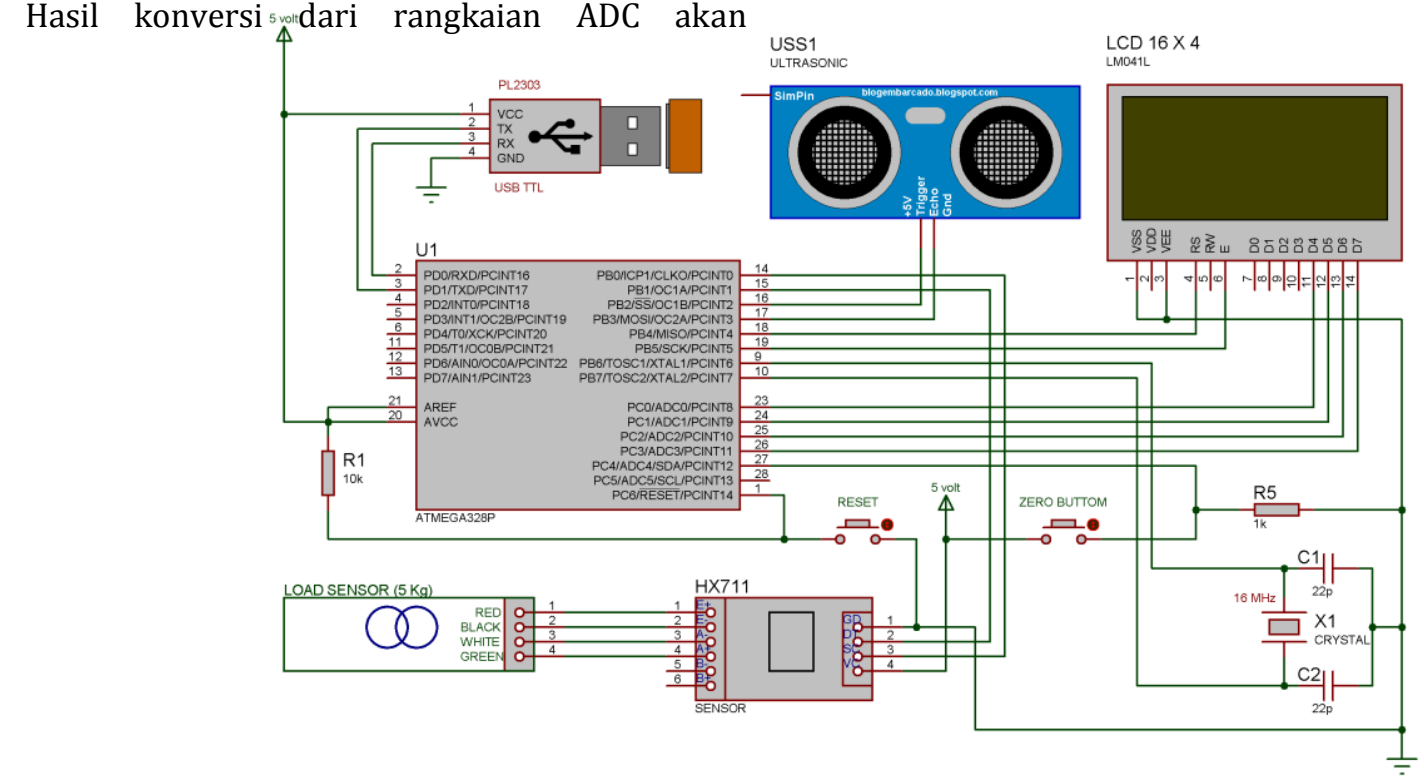

Gambar 4. Skema Rangkaian bagian utama sistem pengolahan data diproses oleh rangkaian mikrokontroler untuk ditampilkan ke display LCD sebagai data berat dalam satuan gram (g). Hasil pengukuran massa ini yang digunakan untuk mengukur gaya berat dan massa jenis benda. Berdasarkan sistem kerja alat keseluruhan, maka dibuat skema rangkaian sistem pengolahan data seperti pada Gambar 4 berikut ini:

\subsection{Pengujian error pengambilan data}

Pengujian error sangat diperlukan pada saat pengambilan data. Hal ini bertujuan untuk mengetahui kelayakan alat yang digunakan. Error hasil pengukuran ini dapat diukur dengan menggunakan rumus:

$$
\begin{gathered}
E_{R M S}=\sqrt{\frac{\sum_{i=1}^{n}\left(\frac{D_{o b s}-D_{k a l}}{D_{o b s}}\right)^{2}}{n}} \\
\% \text { error }=E_{R M S} \times 100 \%
\end{gathered}
$$

dengan:

$$
\begin{array}{ll}
D_{\text {obs }} & =\text { Data observasi, } \\
D_{\text {kal }} & =\text { Data kalkulasi, } \\
\mathrm{N} & =\text { Jumlah data } \\
\mathrm{E}_{\mathrm{RMSE}} & =\text { root mean square error }
\end{array}
$$

\subsection{Perancangan Perangkat Lunak}

Perancangan perangkat lunak ini merupakan alur dari kode program yang akan dibuat agar sistem dapat bekerja dengan baik, seperti pada Gambar 5 berikut ini:

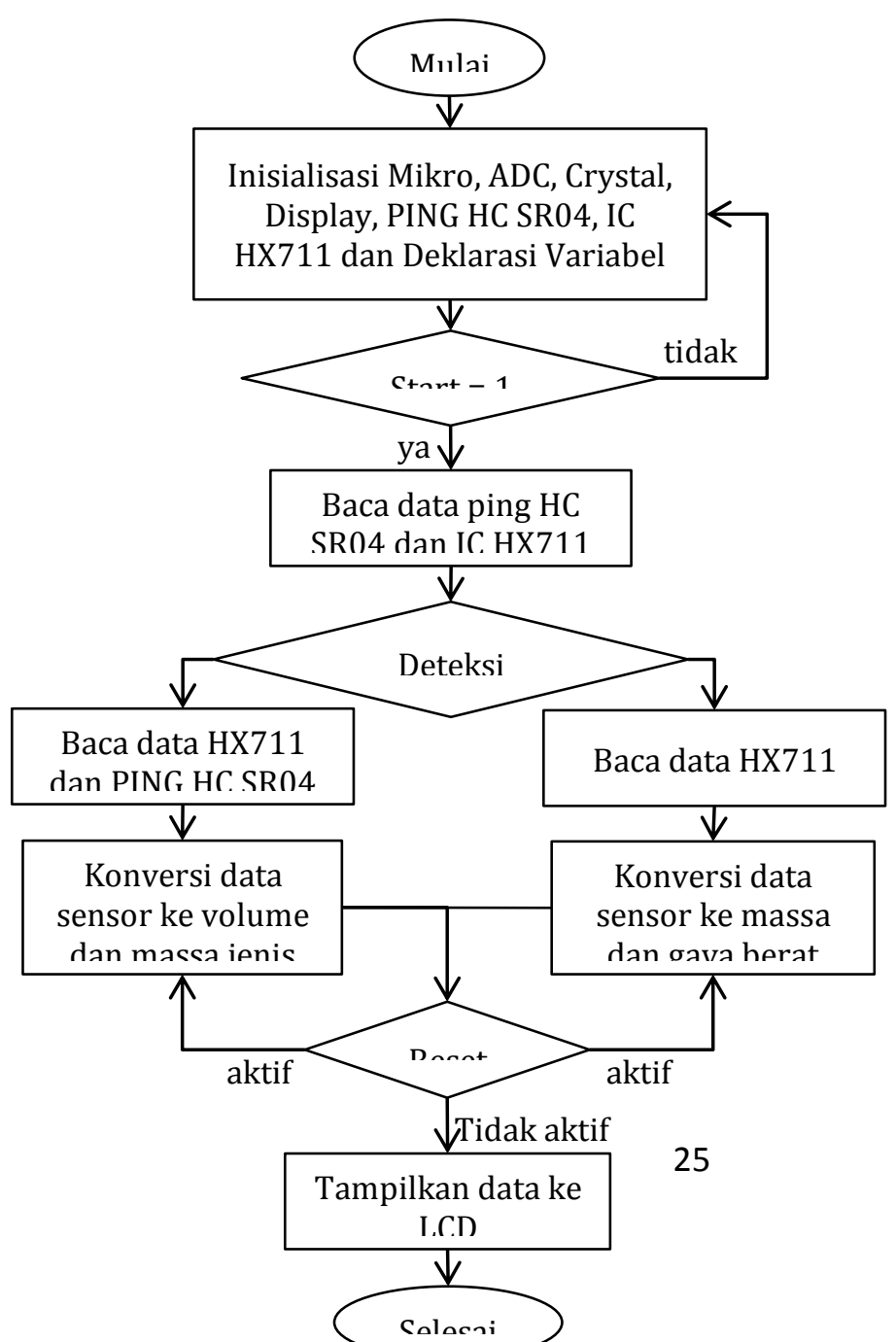


Gambar 5. Perancangan Perangkat Lunak

\section{Hasil dan Pembahasan}

Perangkat alat timbangan digital ini terdiri dari bagian mekanik dan elektronik. Bagian mekanik terdiri dari wadah penyimpanan air yang terbuat dari pipa paralon yang dibuat berbentuk silinder dan tumpuan beban yang terbuat dari kaca akrilik. Sedangkan bagian elektronik terdiri dari sensor beban, sensor jarak, mikrokontroler, IC HX711, LCD dan tombol nol yang digunakan untuk mengubah pengukuran terhadap benda lain yang akan diukur. Pengujian perangkat alat ukur ini perlu dilakukan untuk mengetahui kinerja dari masing-masing bagian mekanik maupun perangkat elektronik.

\subsection{Pengujian sensor beban}

Pengujian ini dilakukan untuk mengetahui hubungan antara tegangan dengan massa yang harus memenuhi persamaan linear.

Tabel 1 Pengujian massa dan tegangan

\begin{tabular}{cc}
\hline Massa $(\mathrm{kg})$ & Tegangan(V) \\
\hline 0,5 & 0,46 \\
1 & 0,96 \\
1,5 & 1,42 \\
2 & 1,90 \\
2,5 & 2,36 \\
3 & 2,86 \\
3,5 & 3,32 \\
4 & 3,79 \\
4,5 & 4,25 \\
5 & 4,71 \\
\hline
\end{tabular}

Dari Tabel 1, dapat disimpulkan bahwa cara kerja sensor ini ketika diberi beban maka akan menimbulkan tegangan sebanding dengan beban yang diberikan. Data awal yang berbentuk analog ini digunakan sebagai acuan dalam kalibrasi pada rangkaian keseluruhan. Setelah data didapat berbentuk analog selanjutnya data diubah menggunakan Analog Digital Converter (ADC) melalui sistem kerja yang dilaksanakan oleh modul IC HX711. Pegubahan data tersebut bertujuan untuk menjadikan data tersebut agar dapat dibaca oleh mikrokontroller selanjutnya data dikirim ke LCD. Data yang diperoleh setelah melakukan pengukuran sangat ideal untuk digunakan sebagai data awal dalam pengukuran massa selanjutnya. Data ini yang menunjukan bahwa sensor beban tersebut dapat digunakan pada penelitian yang dilakukan.

\subsection{Pengujian sensor jarak}

Tabel 2 Pengujian sensor ultrasonik

\begin{tabular}{|c|c|c|c|c|c|c|}
\hline \multirow{2}{*}{$\begin{array}{l}\text { Jarak } \\
(\mathrm{cm})\end{array}$} & \multicolumn{5}{|c|}{ Pengujian } & \multirow{2}{*}{$\begin{array}{l}\text { rata- } \\
\text { rata } \\
(\mathrm{cm})\end{array}$} \\
\hline & 1 & 2 & 3 & 4 & 5 & \\
\hline 5 & 4,99 & 5,00 & 5,10 & 5.10 & 5,00 & 5,04 \\
\hline 6 & 6,02 & 6,05 & 5,99 & 6,00 & 6,02 & 6,02 \\
\hline 8 & 8,00 & 8,10 & 8,00 & 8,00 & 8,00 & 8,02 \\
\hline 10 & 10,00 & 9,99 & 9,98 & 9,98 & 9,98 & 9,99 \\
\hline 12 & 11,87 & 11,98 & 11,98 & 11,97 & 11,97 & 11,95 \\
\hline 14 & 13,95 & 13,97 & 13,97 & 13,97 & 13,97 & 13,97 \\
\hline 16 & 15,95 & 15,95 & 15,94 & 15,95 & 15,95 & 15,95 \\
\hline 18 & 18,10 & 17,96 & 17,95 & 17,98 & 17,89 & 17,98 \\
\hline 20 & 19,98 & 19,95 & 19,89 & 19,97 & 19,97 & 19,95 \\
\hline 22 & 21,97 & 21,97 & 21,97 & 21,95 & 22,94 & 22,16 \\
\hline 24 & 24,00 & 23,99 & 23,98 & 23,97 & 23,97 & 23,98 \\
\hline 26 & 25,98 & 25,98 & 25,98 & 25,88 & 25,95 & 25,95 \\
\hline 28 & 27,98 & 28,10 & 27,97 & 27,97 & 27,87 & 27,98 \\
\hline 30 & 29,95 & 29,97 & 29,97 & 29,96 & 29,98 & 29,97 \\
\hline \multicolumn{7}{|c|}{$\begin{array}{l}\text { Hasil pengujian menunjukan bahwa } \\
\text { pembacaan sensor ultrasonik ping HC SRO4 } \\
\text { sudah sesuai dengan hasil pengukuran jarak } \\
\text { yang dilakukan menggunakan alat ukur manual. } \\
\text { Sensor ultrasonik bekerja berdasarkan } \\
\text { kemampuan penghalang memantulkan kembali } \\
\text { gelombang yang dipancarkan. Gelombang yang } \\
\text { dipantulkan oleh penghalang akan diterima oleh } \\
\text { sistem penghalang yang ada pada sensor ping. } \\
\text { Waktu tempuh dari gelombang dipancarkan } \\
\text { sampai gelombang kembali diterima sensor ping } \\
\text { merupakan waktu total gelombang dipancarkan. } \\
\text { Sedangkan jarak antara sensor ping dengan } \\
\text { penghalang sinyal adalah } 1 / 2 \text { dari jarak sinyal } \\
\text { dipancarkan sampai sinyal kembali diterima } \\
\text { sensor ping. Sehingga jarak total antara sensor } \\
\text { dang penghalang menjadi [7]: }\end{array}$} \\
\hline
\end{tabular}

dengan:

$$
x=v \cdot t / 2
$$

$$
\begin{aligned}
\mathrm{x}= & \text { jarak sensor ke penghalang } \\
\mathrm{v}= & \text { cepat rambat gelombang ultrasonik di } \\
& \text { udara }(344 \mathrm{~m} / \mathrm{s}) \\
\mathrm{t}= & \text { waktu tempuh gelombang ultrasonik }
\end{aligned}
$$

Pengukuran jarak yang dimaksud adalah pengukuran perubahan ketinggian cairan dalam tabung.

\subsection{Pengujian keseluruhan sistem}

Secara garis besar sistem yang dirancang terdiri atas sensor beban dengan berat maksimal $5 \mathrm{Kg}$, IC HX711, sensor ultrasonik HC SR04, mikrokontroler ATMega328 dan LCD yang 
digunakan sebagai tampilan data setiap pengukuran. Sistem keseluruhan alat ini meliputi bagian mekanik dan perangkat elektronik yang sudah diuji. Pengujian massa tidak menggunakan seluruh komponen pada alat. Pada saat pengujian massa, port kabel penghubung ke sensor ultrasonik tidak perlu dipasang. Pengujian massa ini dilakukan dengan membanding hasil pengukuran yang dihasilkan oleh alat terhadap neraca ohaus tipe scoutpro (timbangan standar laboratorium). Benda yang sama dengan benda yang dihitung menggunakan neraca ohaus diletakan ke atas tumpuan beban tepat diatas sensor beban yang sudah dihubungkan ke mikrokontroler serta LCD sebagai tampilan hasil pembacaan. Berikut ditampilkan hasil pengukuran massa benda dalam grafik terhadap timbangan ohaus.

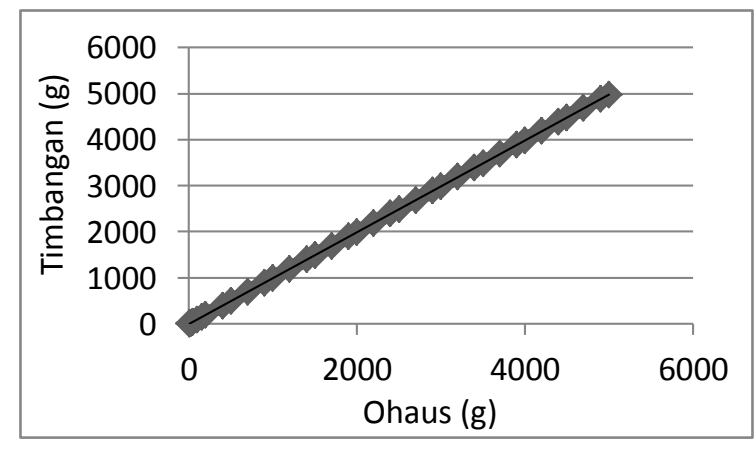

Gambar 6. Grafik hasil pengujian massa menggunakan timbangan digital terhadap neraca ohaus

Dari grafik pada Gambar 6, terlihat hasil pengujian massa yang diukur terhadap neraca ohaus menunjukan hasil yang serupa. Untuk mendapatkan gaya berat benda, maka mikrokontroler akan mengkonversi hasil bacaan timbangan ke dalam satuan Newton. Besarnya percepatan gravitasi bumi yang digunakan pada saat menghitung gaya berat adalah $9,8 \mathrm{~m} / \mathrm{s}^{2}$.

Pengujian massa jenis dilakukan dengan menyambungkan port kabel yang dihubungkan dengan sensor ultrasonik di dalam media penghitungan volume benda. Sebelum melakukan pengujian massa jenis, seluruh komponen bacaan harus diseting menjadi nol, sehingga massa jenis yang terbaca menjadi "nan" seperti pada Gambar 7 berikut ini:

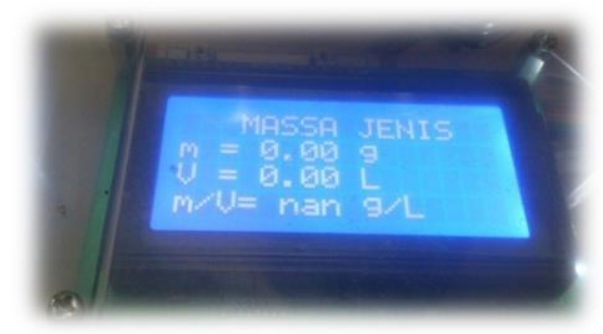

Gambar 7. Sebelum pengukuran massa jenis

Keadaan alat pada kondisi nol bertujuan untuk memperoleh hasil pengukuran yang benar-benar sesuai dengan parameter ukur yang ada. Dengan menggunakan tabung ukur pada pengukuran zat cair. Kemudian untuk mengukur massa jenis benda, alat secara otomatis mengukur perubahan volume yang terbaca melalui sensor ultrasonik.

Mikrokontroler akan membaca nilai yang diberikan oleh sensor ping ini untuk mencari nilai volume yang sesuai dengan program arduino yang diberikan. Dimana, perintah yang diberikan untuk mendapatkan nilai volume adalah luas alas tabung dikalikan tinggi perubahan kenaikan air. Dengan mendapatkan nilai volume dari cairan tersebut maka mikrokontroler akan membaca perintah lain untuk mengkonversikan semua nilai menjadi massa jenis. Perintah yang diberikan adalah massa dibagi dengan volume. Dengan massa yang digunakan adalah massa yang terukur oleh sensor beban.

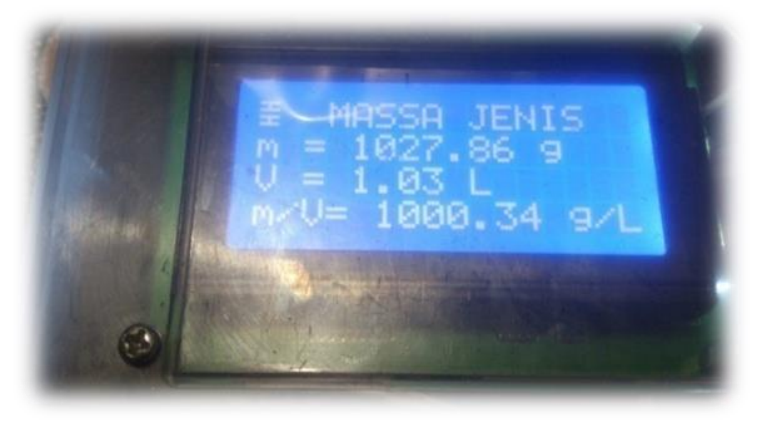

Gambar 8. Pengukuran massa jenis air

Pengujian massa jenis benda tidak beraturan menggunakan wadah yang sudah terisi air. Keseluruhan sistem dikondisikan dalam keadaan nol, sehingga massa jenis sama dengan "nan". Benda yang akan diukur massa jenisnya dimasukan ke dalam wadah yang berisi air tersebut, sehingga sensor ping akan membaca kenaikan tinggi air akibat benda baru yang masuk kedalam wadah tersebut. Kenaikan air tersebut yang akan dibaca sebagai volume total benda tersebut. Mikrokontroler akan menghitung kembali massa jenis sesuai dengan perintah yang diberikan. LCD menampilkan hasil bacaan sesuai perintah dari mikrokontroler untuk menampilkan massa, volume dan massa jenis benda yang terukur.

Pengujian massa jenis benda juga dilakukan dengan menggunakan kelereng. Setiap penambahan kelereng, massa dan volumenya akan bertambah, tetapi massa jenisnya akan selalu sama. Hal ini dikarenakan karakteristik bahan kelereng yang serupa. Tabel 3 berikut ini menunjukan hasil pengukuran massa jenis 
kelereng yang diukur menggunakan alat yang dibuat beserta pengukuran secara manual:

Tabel 3 Pengujian Massa Jenis Kelereng

\begin{tabular}{ccc}
\hline \multirow{2}{*}{ Pengujian } & \multicolumn{2}{c}{ Massa jenis $\left(\mathrm{g} / \mathrm{cm}^{3}\right)$} \\
\cline { 2 - 3 } & Manual & Alat \\
\hline 1 & 2,61 & 2,64 \\
2 & 2,57 & 2,64 \\
3 & 2,67 & 2,62 \\
4 & 2,61 & 2,60 \\
5 & 2,57 & 2,60 \\
6 & 2,57 & 2,61 \\
\hline
\end{tabular}

Dari tabel 3, dapat diketahui bahwa hasil pengujian massa jenis menggunakan alat yang dibuat, memiliki hasil pengukuran yang mendekati hasil perhitungan secara manual. Dengan error pengukuran menggunakan alat ini sebesar $1,64 \%$.

Adapun yang dapat mempengaruhi hasil pengukuran tersebut yaitu:

a. Posisi timbangan pada saat pengukuran harus rata dan tidak miring supaya tidak mempengaruhi regangan yang terjadi pada sensor beban. Begitu juga dengan tabung tidak boleh dengan kondisi tabung miring, karena jika tabung dalam keadaan miring akan membuat perubahan ketinggian cairan sebagai indikator perubahan volume yang dibaca sensor jarak HC SRO4.

b. Arus listrik dari sumber tegangan yang tidak stabil dapat menyebabkan hasil pengukuran jarak pada sensor jarak dan sensor beban tidak akurat. Maka dari itu digunakan sumber tegangan yang memiliki arus listrik stabil.

c. Pemasangan sensor jarak yang tidak tegak lurus terhadap bidang pemantul sinar dapat menyebabkan simpangan hasil pengukuran bertambah besar. Maka dari itu pemasangan alat ukur pada tabung harus berada pada posisi yang tepat.

\section{Kesimpulan}

Berdasarkan penelitian yang telah dilakukan selama proses perancangan, pembuatan dan pengujian alat dapat disimpulkan bahwa alat ini dapat digunakan untuk mengukur massa $(\mathrm{g})$, gaya berat $(\mathrm{N})$ dan massa jenis $\left(\mathrm{g} / \mathrm{cm}^{3}\right)$. Pengukuran massa menggunakan timbangan ini mencapai $4 \mathrm{Kg}$, dengan selisih terbesar $2,45 \mathrm{~g}$ atau sebesar $0,00245 \mathrm{Kg}$ dengan tingkat error pada pengukuran massa sebesar 1,32\%. Massa jenis semua benda juga dapat diukur menggunakan alat ini dengan kenaikan volume air yang dibaca oleh sensor ultrasonik sebagai volume benda yang akan diukur. Pengukuran ini memiliki error sebesar $1,64 \%$.

\section{Daftar pustaka}

[1] Hidayani TU, Miharani T, Rahman A, Hermanto D. Rancang Bangun Timbangan Buah Digital Dengan Keluaran Berat Dan Harga. [Online]. Palembang; 2013 [cited 20165 16. Available from: http://eprints.mdp.ac.id/id/eprint/917

[2] Purnamasari D. Timbangan Digital Berbasis Sensor Flexiforce Dengan Output Suara. 2013 (Skripsi).

[3] Arifin J, Sumardi , Setiawan I. Model Timbangan Digital Menggunakan Load Cell Berbasis Mikrokontroler AT89S51. 2011.

[4] Eduardo AMN, Wanarti P. Pengembangan Perangkat Pembelajaran Media Trainer Digital Weighing Scale Pada Mata Kuliah Fisika 2. Jurnal Pendidikan Teknik Elektro. 2013; 2(1).

[5] Rahmawanto RAT, Rusnindyo EH, Arrofiq M. Pengembangan Timbangan Buah Digital Bernbasis Mikrokontroler ATMEGA 16. In Simposium Nasional RAPI XIII; 2014; Yogyakarta. p. 41-45.

[6] Fikri R, Lapanporo BP, Jumarang MI. Rancang Bangun Sistem Monitoring Ketinggian Permukiman Air Menggunakan Mikrokontroler ATMEGA328P Berbasis WEB Service. POSITRON. 2015; 5(2): p. 42-49.

[7] Prawiroredjo K, Asteria N. Detektor Jarak Dengan Sensor Ultrasonik Berbasis Mikrokontroler. JETri. 2008; 7(2): p. 41-52. 